\title{
Effect of dietary inclusion of cashew nut shell liquid on in vitro and in vivo protein digestibility and utilization in West African dwarf goats
}

*Aderinboye, R. Y., Busari, A. A., Olaoye, O. N., Adelusi, O. O., Adebayo, K. O. and Onwuka, C. F. I.

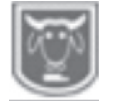

Department of Animal Nutrition, Federal University of Agriculture, Abeokuta, Ogun State, Nigeria,

Abstract

*Correspondence: aderinboyery@funaab.edu.ng; +234903 3795787

Effect of cashew nut shell liquid (CNSL) in diets for West African dwarf (WAD) goats on protein digestibility and utilization was evaluated in vitro and in vivo. Four diets consisting of Panicum maximum supplemented with concentrate pellets containing 0, 5, 10 and 15 $\mathrm{mL} / \mathrm{kg}$ of CNSL were used. Panicum and pellets were combined in ratio 70: 30 of required dry matter (DM). For in vitro experiment, $500 \mathrm{mg}$ ( $n=8$ per diet) of diet samples (DM basis) were incubated at $39^{\circ} \mathrm{C}$ for $48 \mathrm{~h}$ following the procedure of Menke and Steingass (1988). Dry matter and crude protein digestibility, ammonia nitrogen $\left(\mathrm{NH}_{3}-\mathrm{N}\right)$ and bacteria count were determined after 24 and 48 h incubation by recovering feed residues and rumen liquor. For in vivo experiment, twenty-four WAD goats were divided into four groups of six animals each. Each group was fed one of the four diets at $5 \%$ body weight (DM basis). Dry matter and crude protein intake, weight gain, protein efficiency ratio, rumen $\mathrm{NH}_{3}-\mathrm{N}$, bacteria count and crude protein digestibility were measured during 98 days of feeding and digestibility trial. Experiments were arranged in a completely randomized design and data analyzed using one way analysis of variance procedure of SAS (1999). Results showed that $5-15 \mathrm{~mL} / \mathrm{kg} C N S L$ in supplemental pellets reduced $(P<0.05)$ protein digestibility in vitro but increased $(P<0.05)$ total-tract protein digestibility in vivo. In vitro rumen $\mathrm{NH}_{3}-\mathrm{N}$ decreased $(P<0.05)$ with $5-15$ $\mathrm{ml}$ CNSL inclusion after 24 and $48 \mathrm{~h}$. At 30 and 60 days post-feeding, $10-15 \mathrm{~mL} C N S L$ reduced $(P<0.05)$ rumen $\mathrm{NH}_{3}-\mathrm{N}$ in goats Protein efficiency ratio was higher $(P<0.05)$ with $C N S L$ and goats fed $15 \mathrm{~mL} C N S L$ had the highest $(P<0.05)$ protein efficiency ratio. Rumen bacteria population in vitro and in vivo decreased $(P<0.05)$ with $5-15 \mathrm{~mL} C N S L$ in supplemental pellets. In conclusion, the reduced in vitro protein digestibility with reduced $\mathrm{NH}_{3}$-Nproduction and bacteria population in vitro and in vivo suggests an inhibitory effect of CNSL on rumen proteolysis. Cashew nut shell liquid in supplemental pellet for WAD goats up to $15 \mathrm{~mL} / \mathrm{kg}$ therefore inhibited dietary protein breakdown in the rumen with consequent improvement in protein digestibility and utilization at the lower tract.

Keywords: Cashew nut shell liquid, Protein digestibility, Bacteria, Protein efficiency ratio

\section{Introduction}

Rumen microorganisms degrade feed nutrients to produce volatile fatty acids and synthesize microbial protein as an energy and protein supply for the ruminant. This fermentation process incurs losses in form of methane and ammonia nitrogen resulting in energy and protein inefficiencies, respectively that may limit production performance and contribute to the release of pollutants to the environment (Calsamiglia et al., 2007). Bacteria are the most abundant microorganisms in the rumen, of which 40 percent or more have proteolytic activity (Andrade-Montemayor et al., 2009). The proteolytic bacteria ferment dietary proteins into peptides and amino acids which are then further degraded to produce ammonia. Excessive ammonia production in the rumen is a major nutritional 
inefficiency in ruminant animals (Eschenlauer et al., 2002) and if dietary proteins can be protected from ruminal deamination, ammonia declines and the animal has more amino acids for its nutrition (Russell and Mantovani, 2002). Several strategies have been employed to manipulate the rumen in ways that would reduce losses of dietary nutrients. The use of ionophores has proven effective in reducing ruminal degradation of peptides and amino acids, thereby increasing the flow of protein of dietary origin to the small intestine (McGuffey et al., 2001). According to Tedeschi et al. (2003), monensinin the diets of ruminants may decrease protein degradation in the rumen and may increase feed protein utilization by an average of 3.5 percentage units. However, ionophores such as monensin are classified as antibiotics (Hersom and Thrift, 2012) and the use of antibiotics has been restricted in animal feeds for fears of appearance of antibiotic residue in animal products and risk to human health (Landers et al., 2012; Yang et al., 2015 and Beyene, 2016). Recent interests in ruminant nutrition has focused on evaluating other alternatives to antibiotics and the addition of some plant extracts to the rumen have shown inhibitory effect on deamination resulting in lower ammonia nitrogen (Calsamiglia et al., 2007).Cashew nut shell liquid (CNSL) is a by-product from the cashew processing industry with reported antimicrobial activities (Watanabe et al., 2010 and Danielsson et al., 2014). This study was carried out to evaluate the effect of cashew nut shell liquid onprotein digestibility and utilizationin vitro and in vivo in West African dwarf goats.

\section{Materials and methods Experimental site}

This study was carried out at the Animal nutrition laboratory and the small ruminant research farm of the College of Animal Science and Livestock Production, Federal University of Agriculture, Abeokuta. The region is located in the savannah vegetation zone of Southwest Nigeriaand lies between latitude $7^{\circ} 5.5^{\prime}-7^{\circ} 8^{\prime} \mathrm{N}$ and longitude $3^{\circ} 11.2^{\prime}$ - $3^{\circ} 23.5^{\prime} \mathrm{E}$. The annual temperature and humidity are $34.7^{\circ} \mathrm{C}$ and $82 \%$, respectively.

\section{Dietary treatments}

In this study, Panicum maximum was supplemented with concentrate pellets containing CNSL at varying inclusion levels of $0,5,10$ and $15 \mathrm{~mL} / \mathrm{kg}$ to make four different dietary treatments. Diet 1 (control diet) included Panicum maximum supplemented with concentrate pellet containing $0 \mathrm{ml} \mathrm{CNSL}$, Diet 2 included Panicum maximum supplemented with concentrate pellet containing $5 \mathrm{ml} \mathrm{CNSL}$, Diet 3 included Panicum maximum supplemented with concentrate pellet containing $10 \mathrm{ml} \mathrm{CNSL}$ and Diet 4 included Panicum maximum supplemented with concentrate pellet containing $15 \mathrm{ml} \mathrm{CNSL}$. For in vitro and in vivo studies, Panicum maximum was supplemented with the concentrate pellets in the ratio 70 : 30 , respectively of the required dry matter. The Panicum maximum grass used was cut after 6 weeks of growth at $15 \mathrm{~cm}$ above ground level from an established pasture. The concentrate supplement was compounded using wheat offal, rice bran, groundnut cake, brewers' dried grain, cassava flour, bone meal and salt as ingredients. The ingredients were properly mixed to ensure homogeneity. Thereafter, the complete concentrate mixture was incorporated with cashew nut shell liquid at the varying levels of inclusion. Solvent-extracted cashew nut shell liquid with a density of 0.95 was used in this study. The concentrate mixture according to the different levels of CNSL inclusion was thoroughly mixed and then 
processed into pellets of $9 \mathrm{~mm}$ diameter size to give the four different concentrate pellets. Aliquot samples of Panicum maximum and the different concentrate pellets were collected and oven-dried at $60^{\circ} \mathrm{C}$ to constant weight for determination of dry matter. The oven-dried samples were the milled for subsequent determination of proximate, fibre and in vitroanalysis.

\section{In vitro digestibility measurement}

Oven-dried samples of Panicum maximum and the four concentrate pellets were milled through a 1-mm sieve. Approximately 500 $\mathrm{mg}(\mathrm{n}=8$ per dietary treatment $)$ of each diet sample according to the specified ratio of Panicum maximum and pellets in the dietary treatments were weighed into small dacron filter bags of known weights, tiedup and inserted into $100 \mathrm{~mL}$ glass syringes and incubated in vitro following the procedure of Menke and Steingass (1988). A medium $(\mathrm{mL})$ containing 400 distilled water, 0.1 micro-element solution, 200 buffer solution, 200 macro-element solution, 1 resazurin and 40 reduction solution added in this orderwas mixed with rumen liquor in ratio 2:1 (v/v), respectively. The rumen liquor was collected by suction method (Babayemi and Bamikole, 2006) prior to morning feeding from three West African dwarf goats fed with grass $(60 \%)$ and concentrate $(40 \%)$ diet. The rumen liquoron collection was immediately transferred to the laboratory in a prewarmed thermo-flask at $39^{\circ} \mathrm{C}$. It was then strained through a four-layered cheese cloth prior to mixing with the medium. Thirty milliliters $(30 \mathrm{ml})$ of the medium-rumen liquor mixture was introduced into each syringe and incubated at $39 \pm 0.5^{\circ} \mathrm{C}$ for $48 \mathrm{~h}$. Two empty Dacron bags were inserted into separate syringes containing $30 \mathrm{~mL}$ of medium-rumen liquor mixture and included in the run to serve as blanks. Dry matter and crude protein digestibility were determined at 24 and $48 \mathrm{~h}$ after incubation by recovering the residues. Digestibility of dry matter and crude protein were calculated as difference in sample dry matter and crude protein content, respectively before and after incubation with corrections for deposits contributed from the digestion medium made with the blanks.

In vitro ammonia nitrogen determination and bacteria count

Samples of post-incubation digestion liquid were recovered from each syringe for ammonia nitrogen determination and bacterial count. Approximately $10 \mathrm{~mL}$ of post-incubation rumen liquor was sampled for ammonia nitrogen determination at the end of 24 and $48 \mathrm{~h}$ while about $5 \mathrm{ml}$ was collected for bacteria analysis at the end of $24 \mathrm{~h}$.

\section{In vivo protein utilization and digestibility measurement}

Twenty-four growing West African dwarf goats $(8 \pm 2 \mathrm{~kg}$ initial body weight, below 12 months of age) were used for this study. The animals were allowed an adaptation period of one month prior to commencement of the study. After the adaptation period, animals were weighed individually and then divided into four groups of six animals each on weight equalization basis. Each group of animals was allotted to one of the four dietary treatments. Animals were fed at $5 \%$ of their body weight on dry matter basis. Panicum maximum was fed at $70 \%$ of individual animals' daily dry matter requirement while the supplemental pellet made up the remaining $30 \%$. Animals were fed for a period of 84 days during which dry matter intake was estimated on daily basis and weight changes monitored weekly. Protein intake was determined from the daily dry matter intake in order to determine protein efficiency ratio which was calculated by 
dividing the weight gain (g/day) in animals by the protein intake (g/day). At the end of the 84 days of feeding, animals were transferred into metabolic crates with provision for separate collection of faeces and urine. Total faeces voided from individual animals were collected and weighed daily during a seven-day collection period which followed a 5-day adjustment period. About $5 \%$ of total faeces voided per day from each animal were subsampled and oven-dried at $65^{\circ} \mathrm{C}$ for $48 \mathrm{~h}$ until constant weights for dry matter determination. The faeces subsamples for the seven days were then pooled by animal and stored for subsequent analysisof crude protein content. Digestibility of dry matter and crude protein were calculated using the formula for total collection technique (Khan et al. 2003).

\section{In vivo ammonia nitrogen determination and bacteria count}

On days 30 and 60 of the feeding period, samples of rumen liquor were collected three hours post-feeding from individual animals via suction method and immediately filtered through four-layered cheese cloth. Approximately $10 \mathrm{~mL}$ of the filtrate was used for ammonia nitrogen determination. About $5 \mathrm{~mL}$ portion of unfiltered rumen liquorwhich was thoroughly mixed to ensure homogeneity in the liquid and solid phases was subsampled on day 60 at three hours postfeeding for bacteria count.

\section{Laboratory analyses}

The proximate composition of feed and faeces samples were determined by the methods of A. O. A. C. (2000) with crude protein content calculated from the nitrogen (N) content value as $\mathrm{N} \times 6.25$. Ammonia nitrogen in in vitro and in vivo rumen liquor samples were analyzed using the micro-kjeldahl method (A. O. A. C., 2000). The conventional roll-tube technique (Hungate, 1969) was used for culturing and isolation of bacteria from rumen fluid samples. Cultured bacteria was then identified according to Cowan and Steel (1993) and total bacteria count was done according to Baker and Breach (1995) method of total viable counting.

\section{Statistical analysis}

Data collected were subjected to one-way analysis of variance using the analysis of variance procedure of SAS (1999). Significant differences between means were compared at 5\% probability level using the Duncan multiple range test of SAS (1999). The statistical model used was $\mathrm{Y} i j=\mu+\mathrm{T} i+\epsilon_{i j}$ where $\mathrm{Y} i j$ is the observation. $\mu$ is the population mean, $\mathrm{T} i$ is the effect of CNSL inclusion $(\mathrm{I}=1-4)$ in the diet and $\mathrm{Cij}_{\mathrm{ij}}$ is the residual error.

\section{Results}

The nutrient composition of the experimental diets as presented in Table 1. Panicum maximum had crude protein content of $90 \mathrm{~g} / \mathrm{kg}$ DM while the crude protein content of the concentrate pellets ranged between 140 and $142.1 \mathrm{~g} / \mathrm{kg}$ DM. The inclusion of CNSL in the concentrate pellets did not $(\mathrm{P}>0.05)$ alter the protein content of the diet. Ether extract and metabolizable energy contents were however, higher with increasing levels of CNSL in the pellet diets.

The in vitro protein digestibility, ammonia production and bacteria population in response to dietary inclusion of CNSL is presented in Table 2. At 24 and $48 \mathrm{~h}$ postincubation, CNSL caused a significant $(\mathrm{P}<$ $0.05)$ reduction in protein digestibility at 5 , 10 and $15 \mathrm{~mL}$ of inclusion relative to the control. At $24 \mathrm{~h}$, it was observed that higher doses of $10-15 \mathrm{~mL}$ did not $(\mathrm{P}>0.05)$ vary in their effect compared with $5 \mathrm{ml}$ inclusion level but at $48 \mathrm{~h}$, there was a further reduction in protein digestibility at $10-15$ 
Table 1: Gross and nutrient composition (g/kg) of experimental diets

\begin{tabular}{|c|c|c|c|c|c|c|}
\hline \multirow[b]{2}{*}{ Gross composition } & \multicolumn{4}{|c|}{$\begin{array}{l}\text { Concentrate pellet containing varying } \\
\text { levels of cashew nut shell liquid }\end{array}$} & & \\
\hline & $0 \mathrm{ml} / \mathrm{kg}$ & $5 \mathrm{ml} / \mathrm{kg}$ & $10 \mathrm{ml} / \mathrm{kg}$ & \multicolumn{2}{|l|}{$15 \mathrm{ml} / \mathrm{kg}$} & \\
\hline Wheat offal & 40 & 40 & 40 & \multicolumn{2}{|l|}{40} & \\
\hline Rice bran & 14 & 14 & 14 & \multicolumn{2}{|l|}{14} & \\
\hline Soya bean meal & 5 & 5 & 5 & \multicolumn{2}{|l|}{5} & \\
\hline Brewers' dried grain & 18 & 18 & 18 & \multicolumn{2}{|l|}{18} & \\
\hline Cassava flour & 20 & 20 & 20 & \multicolumn{2}{|l|}{20} & \\
\hline Bone meal & 2 & 2 & 2 & \multicolumn{2}{|l|}{2} & \\
\hline Salt & 1 & 1 & 1 & \multicolumn{2}{|l|}{1} & \\
\hline Cashew nut shell liquid $^{1}$ & - & + & ++ & \multicolumn{2}{|l|}{+++} & \\
\hline Total & $1000 \mathrm{~g}$ & $1000 \mathrm{~g}$ & $1000 \mathrm{~g}$ & $1000 \mathrm{~g}$ & & \\
\hline \multicolumn{5}{|l|}{ Nutrient composition ${ }^{2}$} & SEM & $\begin{array}{l}\text { Panicum } \\
\text { maximum }\end{array}$ \\
\hline Dry matter (as fed) & 958.0 & 965.2 & 967.0 & 963.4 & 3.9 & 407.0 \\
\hline Crude protein & 140.2 & 141.1 & 140.0 & 142.1 & 2.2 & 90.0 \\
\hline Ether extract & 83.8 & 106.2 & 111.5 & 115.2 & 4.2 & 32.49 \\
\hline Organic matter & 893.0 & 894.5 & 894.0 & 895.0 & 1,5 & 928.8 \\
\hline Neutral detergent fibre & 471.0 & 468.8 & 465.3 & 464.1 & 1.8 & 485.6 \\
\hline Acid detergent fibre & 203.0 & 198.2 & 197.3 & 190.7 & 2.4 & 309.2 \\
\hline Acid detergent lignin & 91.0 & 92.4 & 91.3 & 92.8 & 1.5 & 100.5 \\
\hline Metabolizable energy $(\mathrm{kcal} / \mathrm{kg})$ & $3194^{\mathrm{b}}$ & $3296^{\mathrm{a}}$ & $3318^{\mathrm{a}}$ & $3344^{\mathrm{a}}$ & 19.19 & 2330 \\
\hline \multicolumn{7}{|c|}{$\begin{array}{l}\text { a,b Mean within the same row with different superscript are significantly different }(\mathbf{P}<0.05) \\
\text { SEM: standard error of mean; }{ }^{C} \text { ashew nut shell liquid included as feed additive to a complete concentrate diet at } 0 \mathrm{~m} / / \mathrm{kg}(), 5 \mathrm{ml} / \mathrm{kg} \\
(+), 10 \mathrm{ml} / \mathrm{kg}(++) \text { and } 15 \mathrm{ml} / \mathrm{kg}(+++) ;{ }^{2} \text { Nutrient composition in } \mathrm{g} / \mathrm{kg} \text { dry matter }\end{array}$} \\
\hline \multicolumn{3}{|c|}{$\begin{array}{l}\text { mL inclusion relative to the digestibility } \\
\text { values at } 5 \mathrm{~mL} \text { inclusion. In vitro ammonia } \\
\text { production reduced significantly }(\mathrm{P}<0.05) \\
\text { with inclusion of } 5-15 \mathrm{~mL} \text { of } \mathrm{CNSL} \text { at } 24 \\
\text { and } 48 \mathrm{~h} \text { post-incubation. At both } \\
\text { incubation hours, diets without CNSL } \\
\text { produced the highest }(\mathrm{P}<0.05)\end{array}$} & \multicolumn{4}{|c|}{$\begin{array}{l}\text { concentration of ammonia while diets } \\
\text { containing } 15 \mathrm{ml} \text { CNSL produced the } \\
\text { lowest }(\mathrm{P}<0.05) \text { concentration of } \\
\text { ammonia. When bacteria population was } \\
\text { determined at } 24 \mathrm{~h} \text { post incubation period, } \\
\text { there was a decreased }(\mathrm{P}<0.05) \text { in bacteria } \\
\text { population in rumen fluid with } 5-15 \mathrm{~mL} \text { of } \\
\text { CNSL inclusion relative to the control. }\end{array}$} \\
\hline
\end{tabular}

Table 2: In vitro microbial protein degradation, ammonia production and bacteria population in response to diets containing cashew nut shell liquid

\begin{tabular}{|c|c|c|c|c|c|}
\hline \multirow[b]{2}{*}{ Parameter } & \multicolumn{4}{|c|}{ Levels of dietary cashew nut shell liquid inclusion } & \multirow[b]{2}{*}{ SEM } \\
\hline & 0 mg/kg DM & $5 \mathrm{mg} / \mathrm{kg} \mathrm{DM}$ & $10 \mathrm{mg} / \mathrm{kg} \mathrm{DM}$ & $15 \mathrm{mg} / \mathrm{kg} \mathrm{DM}$ & \\
\hline $\begin{array}{l}\text { In vitro protein } \\
\text { degradation, } \% \text { : }\end{array}$ & & & & & \\
\hline $24 \mathrm{~h}$ post incubation & $64.67^{\mathrm{a}}$ & $60.61^{\mathrm{b}}$ & $58.89^{\mathrm{b}}$ & $58.80^{\mathrm{b}}$ & 0.71 \\
\hline $\begin{array}{l}48 \mathrm{~h} \text { post incubation } \\
\text { In vitro ammonia } \\
\text { production, } \mathrm{mg} / 100 \mathrm{~mL} \text { : }\end{array}$ & $73.39^{\mathrm{a}}$ & $70.66^{\mathrm{b}}$ & $67.74^{\mathrm{c}}$ & $65.83^{\mathrm{c}}$ & 0.53 \\
\hline $24 \mathrm{~h}$ post incubation & $20.83^{\mathrm{a}}$ & $16.53^{\mathrm{b}}$ & $14.92^{\mathrm{bc}}$ & $11.88^{\mathrm{c}}$ & 1.00 \\
\hline $48 \mathrm{~h}$ post incubation & $25.90^{\mathrm{a}}$ & $19.40^{\mathrm{b}}$ & $17.33^{\mathrm{bc}}$ & $14.17^{\mathrm{c}}$ & 1.32 \\
\hline $\begin{array}{l}\text { Bacteria population } \\
(\mathrm{CFU} / \mathrm{ml})^{1}\end{array}$ & $2.16^{\mathrm{a}}$ & $1.22^{\mathrm{b}}$ & $1.18^{\mathrm{b}}$ & $1.05^{\mathrm{b}}$ & 0.14 \\
\hline
\end{tabular}


Table 3 shows the protein digestibility, protein efficiency ratio, rumen ammonia nitrogen concentration and bacteria population in West African dwarf goats fed supplemental pellets containing varying levels of CNSL. Protein digestibility was higher $(\mathrm{P}<0.05)$ in goats fed pellets containing $10-15 \mathrm{~mL}$ of CNSL inclusion relative to the digestibility value in goats fed the control diet. Protein efficiency ratio was higher $(\mathrm{P}<0.05)$ with increasing levels of CNSL with the highest $(\mathrm{P}<0.05)$ ratio observed in goats fed pellets containing 15 ml CNSL. Similar to the in vitro results, the inclusion of CNSL in the diet of goats caused a reduction $(\mathrm{P}<0.05)$ in the concentration of ammonia nitrogen in the rumen. At 30 days of feeding, rumen ammonia nitrogen reduced $(\mathrm{P}<0.05)$ from $30.38 \mathrm{mg} / 100 \mathrm{~mL}$ to between 13.27 and $25.11 \mathrm{mg} / 100 \mathrm{~mL}$ while at 60 days of feeding, concentration reduced $(\mathrm{P}<0.05)$ from $38.92 \mathrm{mg} / 100 \mathrm{~mL}$ to between 18.06 and $26.26 \mathrm{mg} / 100 \mathrm{~mL}$. Bacteria count in the rumen of goats revealed a decrease $(\mathrm{P}<$ 0.05) when pellets containing CNSL were fed.

Table 3 : In vivo protein utilization, digestibility, rumen ammonia production and bacteria count in West African dwarf goats in response to dietary cashew nut shell liquid inclusion

\begin{tabular}{|c|c|c|c|c|c|}
\hline \multirow[b]{2}{*}{ Parameter } & \multicolumn{4}{|c|}{ Levels of dietary cashew nut shell liquid inclusion } & \multirow[b]{2}{*}{ SEM } \\
\hline & 0 mg/kg DM & $5 \mathrm{mg} / \mathrm{kg} \mathrm{DM}$ & $10 \mathrm{mg} / \mathrm{kg} \mathrm{DM}$ & $15 \mathrm{mg} / \mathrm{kg} \mathrm{DM}$ & \\
\hline Protein intake, $\mathrm{g} / \mathrm{d}$ & $61.67^{\mathrm{a}}$ & $54.95^{\mathrm{b}}$ & $51.00^{\mathrm{c}}$ & $49.42^{\mathrm{d}}$ & 0.30 \\
\hline Animal weight gain, g/d & $23.4^{\mathrm{c}}$ & $29.2^{\mathrm{b}}$ & $30.1^{\mathrm{ab}}$ & $31.0^{\mathrm{a}}$ & 0.62 \\
\hline Protein efficiency ratio & $0.38^{\mathrm{c}}$ & $0.53^{\mathrm{b}}$ & $0.60^{\mathrm{b}}$ & $0.64^{\mathrm{a}}$ & 0.24 \\
\hline $\begin{array}{l}\text { Protein digestibility, } \% \\
\text { In vivo rumen ammonia } \\
\text { production, } \mathrm{mg} / 100 \mathrm{~mL}^{1} \text { : }\end{array}$ & $67.38^{\mathrm{b}}$ & $68.76^{\mathrm{ab}}$ & $69.39^{\mathrm{a}}$ & $70.12^{\mathrm{a}}$ & 0.33 \\
\hline 30 days post feeding & $30.38^{\mathrm{a}}$ & $25.11^{\mathrm{ab}}$ & $16.08^{\mathrm{bc}}$ & $13.27^{\mathrm{c}}$ & 2.82 \\
\hline 60 days post feeding & $38.92^{\mathrm{a}}$ & $26.26^{\mathrm{b}}$ & $20.11^{\mathrm{b}}$ & $18.06^{\mathrm{b}}$ & 3.20 \\
\hline $\begin{array}{l}\text { Bacteria population } \\
(\mathrm{CFU} / \mathrm{ml})^{2}\end{array}$ & $2.15^{\mathrm{a}}$ & $1.80^{\mathrm{b}}$ & $1.68^{\mathrm{b}}$ & $1.61^{\mathrm{b}}$ & 0.07 \\
\hline
\end{tabular}

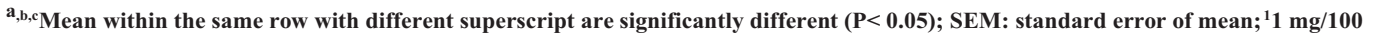
$\mathrm{mL}$ is equivalent to $1 \mathrm{mg} / \mathrm{dL}$ or $10 \mathrm{mg} / \mathrm{L}$; ${ }^{2}$ Bacteria population determined in the rumen at $3 \mathrm{~h}$ after feeding on day 60

\section{Discussion}

The similarity in crude protein content of the pellet diets implies that CNSL inclusion at $5-15 \mathrm{~mL} / \mathrm{kg}$ inclusion did not alter the protein content of the diet and would therefore not bind dietary proteins at these inclusion levels. The variation in ether extract however was attributed to extra contributions of oil from CNSL which was also thought to consequently increase the metabolizable energy content of the pellet diets. The reduction effect of CNSL on protein digestibility in vitro suggests that CNSL reduced substrate colonization by proteolytic microbes thereby reducing degradation. Although studies with cashew nut shell liquid with goats are scarce, certain plant oils have similarly been associated with reduction of proteins digestion in the rumen (McIntosh et al., 2003; Salamatazar et al., 2011). According to Hart et al. (2008), the main effects of plant oils in the rumen include reduced protein and starch degradation and an inhibition of amino acid degradation. One of the modes of action suggested by these authors for plant oils was on inhibition of hyper-ammonia producing bacteria. The similarity in the effect of $5-15 \mathrm{~mL} \mathrm{CNSL}$ at $24 \mathrm{~h}$ and the difference in the effect of 10-15 mL CNSL inclusion at $48 \mathrm{~h}$ compared with $5 \mathrm{~mL}$ inclusion level indicates that the effect of 
CNSL on protein digestibility is dependent on the level of inclusion and retention time in the rumen. A longer retention time would possibly be required at higher inclusion levels.

The reduction in in vitro ammonia production at 24 and $48 \mathrm{~h}$ with $5-15 \mathrm{~mL}$ of CNSL inclusion was assumed as the consequent effect of reduced in vitro protein digestibility. The similar effect of CNSL observed on ammonia production in vivo confirms CNSL to have an inhibitory effect on rumen protein degradation. The reduced ammonia production suggests an increase in the supply of dietary protein to the lower tract and decreased supply of ammonia for microbial growth. The increased in vivo protein digestibility and improved protein efficiency ratio with CNSL substantiates possibility for increased flow of proteins to the lower tract allowing for improved utilization of dietary proteins. On the other hand however, the reduction in bacteria population observed in our study in vitro and in vivo could confirm a reduction in the availability of ammonia for microbial synthesis. According to Leng (1991), on a forage based diet, rumen ammonia level should be above $200 \mathrm{mg}$ nitrogen/L. Kanjanapruthipong and Leng (1998) reported the level of rumen ammonia nitrogen required for optimum microbial synthesis to be between $50-238 \mathrm{mg} / \mathrm{L}$ while a minimum of $5 \mathrm{mg} / \mathrm{dL}(50 \mathrm{mg} / \mathrm{L})$ of $\mathrm{NH}_{3}-\mathrm{N}$ concentration in the rumen is considered adequate for microbial protein production (NRC., 1985). Concentration of ammonia in the rumen with and without CNSL in this study was well above $50 \mathrm{mg} / \mathrm{L}$ indicating its adequacy for optimum microbial synthesis. The reduced bacteria population with inclusion of CNSL at $5-15$ $\mathrm{mL}$ could therefore, not pose any detrimental effect on rumen bacteria survival and normal rumen function but only probably saved excessive utilization of dietary protein in the rumen. Similar to our results, when CNSL was administered to non-lactating (Shinkai et al., 2012) and lactating cows (Branco et al., 2015), there was a reported decrease in bacteria population. The reduction in bacterial population in the rumen could be due to the antibacterial activity of the active compounds in CNSL. Cashew nut shell liquid contains some active compounds which have been reported to exhibit antibacterial properties (Watanabe et al., 2010; Parasa et al., 2011 and Danielsson et al., 2014). Although bacteria species related to proteolysis were not identified in this study, the reduction in bacteria population, the concomitant reduction in protein degradation in vitro and reduced in vitro and in vivo ammonia production could be an evidence of decreased proteolytic bacteria.

\section{Conclusion}

The study showed that cashew nut shell liquid inclusion in supplemental pellets for West African dwarf goats at $5-15 \mathrm{~mL} / \mathrm{kg}$ reduced in vitro protein digestibility, in vitro and in vivo ammonia nitrogen production and rumen bacteria population. However, in vivo protein digestibility at the lower tract and protein efficiency ratio was higher with CNSL inclusion. The effect of CNSL in supplemental pellets for goats reflects inhibition of protein breakdown in the rumen and possible increase in the flow of un-degradable proteins to the lower tract for better utilization particularly at $15 \mathrm{~mL} / \mathrm{kg}$ of inclusion. The reduction effect of CNSL on rumen ammonia production is however, not likely threaten the survival of bacteria in the rumen at the level of inclusion as rumen ammonia concentrations were well above the minimum level for microbial growth. 


\section{Acknowledgement}

The authors acknowledge the Tertiary Education Trust Fund (TETFund), Nigeria for the funding of this study under the 2013/2014 TETFund Institution-based Research Intervention Allocation for a project titled, "Utilization of cashew nut shell liquid as a dietary strategy to manipulate rumen fermentation for improved nutritional performance of ruminants".

\section{References}

Andrade-Montemayor, H., García, G. T. and Kawas, J. 2009. Ruminal fermentation modification of protein and carbohydrate by means of roasted and estimation of microbial protein synthesis. Revista Brasileira de Zootecnia, 38 ( s p e ) : $277-291$. https://dx.doi.org/10.1590/S151635982009001300028

A. O. A. C., 2000. Official methods of analysis of AOAC. International 17th edition; Gaithersburg, MD, USA.

Babayemi, O. J. and Bankole, M. A. 2006. Effects of Tephrosia candida DC Leaf and its Mixtures with Guinea Grass on in vitro Fermentation Changes as Feed for Ruminants in Nigeria. Pakistan Journal of Nutrition 5 (1): 14-18.

Baker, F. J. and Breach, M. R. 1995. Total viable counting. Medical microbiology techniques. Butterworth Publishers, 420 - 424.

Beyene, T. 2016. Veterinary drug residues in food-animal products: its risk factors and potential effects on public health. Journal of Veterinary Science and Technology 7: 285. DOI:10.4172/21577579.1000285
Branco,A. F., • G i a 1 l o n g o , F ., • Frederick, T., Weeks, H., Oh, J. and Hristov, A. N., 2015. Effect of technical cashew nut shell liquid on rumen methane emission and lactation performance of dairy cows. Journal of Dairy Science 98 (6): 4030-4040.

Calsamiglia, S., Busquet, M., Cardozo, P. W., Castillejos, L. and Ferret, A. 2007. Invited review: Essential oils as modifiers of rumen microbial fermentation. Journal of Dairy Science 90: 2580-2595.

Cowan, S. T. and Steel, K. J. 1993. Enterobacteriacea. In: G. I. Barrow, R. K. A. Felthan, (Eds). Manual for identification of medical bacteria ( $3{ }^{\text {rd }}$ edition), Cambridge University press, United Kingdom, 213 - 218.

Danielsson, R., Werner-Omazic, A., Ramin, M., Schnürer, A., Griinari, M., Dicksved, J. and Bertilsson, J. 2014. Effects on enteric methane production and bacterial and archaeal communities by the addition of cashew nut shell extract or glycerol: An in vitro evaluation. Journal of Dairy Science 97: 5729-5741. http://dx.doi.org/10.3168/jds.2014 $-7929$

Eschenlauer, S. C. P., McKain, N., Walker, N. D., , N. R., Newbold, C. J. and Wallace, R. J. 2002. Ammonia production by ruminal microorganisms and enumeration, isolation, and characterization of bacteria capable of growth on peptides and amino acids from the sheep rumen. Applied and Environmental Microbiology 68(10): 4925-4931. DOI: $10.1128 /$ A EM.68.10.49254931.2002 
Hart, K. J., Yáñez-Ruiz, D. R., Duval, S. M., McEwan, N. R. and Newbold, C. J. 2008. Plant extracts to manipulate rumen fermentation. Animal Feed Science and Technology 147 (1-3): 8-35 https://doi.org/10.1016/j.anifeedsc i.2007.09.007

Hersom, M. and Thrift, T. 2012. Application of Ionophores in Cattle Diets. University of Florida/Institute of Food and Agricultural Sciences Extension $\begin{array}{lllllllllll}\mathrm{s} & \mathrm{e} & \mathrm{r} & \mathrm{v} & \mathrm{i} & \mathrm{c} & \mathrm{e} & \mathrm{s} & \text {. }\end{array}$ http://edis.ifas.ufl.edu/pdffiles/AN /AN28500.pdf

Hungate, R. E. 1969. A roll tube method for cultivation of strict anaerobes. In: Norris, J. R., Ribbons, D. W. (eds.): Methods in microbiology. Academic Press, London and New York, 3B, 117-132.

Kamalak, A., Canbolat, O., Gurbuz, Y. and Ozay, O. 2005. Protected Protein and Amino Acids in Ruminant Nutrition. Journal of Science and Engineering 8(2): 84 87

Kanjanapruthipong, J. and Leng, R. A. 1998. The effects of dietary urea on microbial population in the rumen of sheep. Asian Journal of Animal Science 11 (6): 661-672.

Khan, M. A., Mahr-Un-Nisa and Sarwar, M., 2003. Techniques measuring digestibility for the nutritional evaluation of feeds. International Journal of Agriculture and Biology, 5, 91-94

Landers, T. F., Cohen, B., Wittum, T. E. and Larson, E. L. 2012. A Review of Antibiotic Use in Food Animals: Perspective, Policy, and Potential. Public Health Report 127(1): 4-22.
$\begin{array}{lcl}\mathrm{D} & \mathrm{O} & \mathrm{I} \\ 10.1177 / 003335491212700103\end{array}$

Leng, R. A. 1991. Application of biotechnology to nutrition of animals in developing countries. FAO Animal Production and Health Paper. Food and Agriculture Organization of the $\mathrm{U} n \mathrm{i} \mathrm{t}$ e $\mathrm{d}$ a $\mathrm{t}$ i o n s, Romehttp:/www.fao.org/docrep/ 004/T0423E/T0423E03.htm\#ch3. 3

McGuffey, R. K., Richardson, L. F. and Wilkinson, J. I. D. 2001. Ionophores for dairy cattle: current status and future outlook. Journal of Dairy Science 84 (supplement): E $194-$ E 203 D O I : http://dx.doi.org/10.3168/jds.S00 22-0302(01)70218-4

McIntosh, F. M., Williams, P., Losa, R., Wallace, R. J., Beever, D. A. and Newbold, C. J. 2003. Effects of essential oils on ruminal microorganisms and their protein metabolism. Applied and Environmental Microbiology 69 (8): 5011-5014

Menke, K. H. and Steingass, H. 1988. Estimation of the energetic feed value obtained from chemical analysis and gas production using rumen fluid. Animal Research and Development 28: 7-55.

NRC. 1985. Ruminant Nitrogen Usage. National Academy Press, Washington, D. C., USA. p. 138.

Parasa, L. S., Tumati, S. R., Kumar, L. C. A., Chigurupati, S. P. and Rao, G. S. 2011. In vitro antimicrobial activity of cashew (Anacaardium occidentale, L.) nuts shell liquid against methicillin resistant Staphylococcus aureus clinical isolates. International Journal of 
Pharmacy and Pharmaceutical Sciences 3 (4): 436 - 440

Russell, J. B and Mantovani, H. C. 2002. The bacteriocins of ruminal bacteria and their potential as an alternative to antibiotics. Journal of Molecular Microbiology and Biotechnology 4(4): 347-355.

Salamatazar, M., Salamatdoust-nobar, R., Sis, N. M., Shabestari, A. N., Najafyar, S., Khodaparast, B., Amini, P. N. and Rezayi, N. 2011. Effects of Thyme methanolic Extract on Ruminal Protein Degradation of Soybean Meal using Nylon Bag Technique. Current Research Journal of Biological Sciences 3(6): 612-615, 2011

SAS, 1999. Statistical Analysis Systems user's guide (Statistics, Version.8). SAS Institute Inc, Cary.

Shinkai, T., Enishi, O., Mitsumori, M., Higuchi, K., Kobayashi, Y., Takenaka, A., Nagashima, K., Mochizuki, M. and Kobayashi, Y. 2012. Mitigation of methane production from cattle by feeding cashew nut shell liquid. Journal of Dairy Science 95: 5308-5316
Tedeschi, L. O., . and Tylutki, T. P. 2003. Potential environmental benefits of ionophores in ruminant diets. Journal of Environmental Quality 32(5): 591-602.

Watanabe, Y., Suzuki, R., Koike, S., Nagashima, K., Mochizuki, M., Forster, R. J. and Kobayashi, Y. 2010. In vitro evaluation of cashew nut shell liquid as a methaneinhibiting and propionateenhancing agent for ruminants. Journal of Dairy Science93: 52585267.

Yang, C., Chowdhury, M. A. K., Hou, Y. and Gong, J. 2015. Phytogenic compounds as alternatives to infeed antibiotics: potentials and challenges in application. Pathogens 4, 137-156. DOI: 10.3390/pathogens4010137.

Received: $14^{\text {th }}$ November, 2017

Accepted: $20^{\text {th }}$ February, 2018 